\title{
Study on Undergraduates Employment Ideological Education Practice
}

\author{
Lirong Ai \\ Wuhan Institute of Shipbuilding Technology, Wuhan, China \\ Email:3247438@qq.com
}

Received 15 February 2015; accepted 5 March 2015; published 9 March 2015

Copyright (C) 2015 by author and Scientific Research Publishing Inc.

This work is licensed under the Creative Commons Attribution International License (CC BY).

http://creativecommons.org/licenses/by/4.0/

(c) (i) Open Access

\begin{abstract}
The critical solution to the employment of graduates with difficulties in finding a job, which is initially contributed to the stresses and strains of the career guidance in higher vocational colleges, is to solve the problem of ideological and political education the graduates should have. This paper analyzed the data from a survey, taken in a vocational college in Hubei Province in China, on what kinds of problems and why the graduates with difficulties in finding a job might suffer from in their minds. And then the reasonable comments and proper suggestions were presented to solve the problem in higher vocational colleges in China under the guidance of related theories of Chinese and Western ideological and political education.
\end{abstract}

\section{Keywords}

Employment, Ideological and Political Education, Practical Study, Career Guidance

\section{Introduction}

The employment problem of graduates with difficulties in finding a job is concerned with the actual effect of higher vocational college career guidance work. It is initially contributed to the stresses and strains of the career guidance in higher vocational colleges and is really a hard nut to crack for most of the career guiders in higher vocational colleges. There are great difficulties for them to break through the choke point for the employment and solve the problem of those graduates with difficulties in finding a job. To solve the thorny problem more effectively, the inspiration and experience of western ideological and political education can be taken as a reference with the combination of the practical experience of the Communist Party of China, that is, analyzing the ideological motion of such graduates practically, realistically, and creatively under the guide of all related theories (Qiu, 2011). 


\section{Related Theories}

\subsection{Inspiration of Western "Ideological and Political Education"}

There is no "ideological and political education" in western countries. "Education on the Rights and Duties of Citizens", "Education on Moral", "Education on History" and the "Education on Political Socialization" of them have no substantial distinction with the ideological and political education in China. The former president of International Studies School of the U.S. Department of Education said: "The duty of our school is to teach students to grasp the technique of political socialization. It is called ideological and political education or moral education in China. We call it citizenship education or political socialization.” The western ideological and political education takes the humanism as the ideological foundation. It emphasizes the importance of the main body position of the educatees, pays attention to the humanization, lives and practice in the educational activities and weakens the power of the instruction of education itself. Self-development is supposed for educatees instead of their socialization. Meanwhile, infiltration education is also part of the emphasis. The educators are provided the education environment to infiltrate the educational contents and educational goals into all kinds of forms based on nonteaching models featured in concealment, indirection and universality. The practical education refers to design some practical activities according to the educational contents and goals. Then the educatees can acquire the educational contents by means of the participation of the activities. the psychological education is caught much attention too in Western countries and some colleges set up psychology consulting institutions to help students solve the conflictions during the process of cognition, remove the mental obstacles, dig out their potential and enhance their mental adaptability.

\subsection{The Basic Experience of the Ideological and Political Education in China}

The Communist Party of China has accumulated rich experience for the ideological and political education. It must be based on the factual and realistic work style (Shishiqiushi), the principles of integrating theory with practice and pragmatism.

Comrade Mao Tse-tung pointed out, in Remodeling Our Study in 1941, that in Shishiqiushi, shishi refers to everything existing in the real world, the last shi means the internal relations among them, that is, the rules among the things, and qiu requires us to pursue and study for the rules. We should find out and take as the guide of our actions the internal relations of the events occurring around us from the actual conditions of both inside and outside of all the districts, counties, provinces, or our country. The target of ideological and political education is people. The ideological situation of people will have diversity and complexity owing to the different status with respect to the relations among people and different environments they are in, different educational background and personality and various thinking patterns. The ideological and political education must face these kinds of diversity and complexity and respect the physical variance. It couldn't be subjectified and the sweeping approach should be avoided. When we engage in ideological and political education, we must face the truth and reality and respect people in all societies, levels, types and ages. Only in this way, the education has practical effect.

The principle of integrating theory with practice is one of the universal rules of human cognitive activities. Comrade Mao Tse-tung pointed out that "we should study Marxism and try to integrate it with the concrete practice of our country; we do need a standard, but we must correct the standardism deviating from the reality; and when we develop the political and ideological work, suitable measures should be taken in different conditions in accordance with the changes of locality, time and issues involved. Working while ignoring the differences and changes won't achieve good effect.”

According to the diversity of the educational contents and the complexity of the education targets, the Communist Party of China has laid and is laying great stress on using the proper methods and ways to develop ideological and political education. Comrade Mao Tse-tung said that "It is not enough to set tasks; we must also solve the problem of the methods for carrying them out. If our task is to cross a river, we cannot cross it without a bridge or a boat. Unless the bridge or boat problem is solved, it is idle to speak of crossing the river. Talking about the task is useless unless the problem of methods is solved.” After nearly 90 years of ideological and political education practice, the Communist Party of China has accumulated a great deal of forms, models, ways, arts and methods of education and they have realized that pragmatism and creativity are the essential (Yang, 2013). 


\section{Latest Trends of the Thoughts of Graduates}

In order to keep a good grip on the latest trends of the thoughts of graduates with difficulties in finding jobs, the author made up the self-designed questionnaire to them. The questions related to the preparations of work, employment will, the job psychology and the value views. There are 752 participates in the questionnaire survey, A total of 726 completed the questionnaire. The recovery was $96.54 \%$.

\subsection{Questionnaire Survey}

\subsubsection{Employment Preparation}

The author carried out a survey through two questions in order to achieve complete understanding of students' plan after graduation and their job application channels.

As we can see from the Table 1, only a few unemployed graduates had the plan of starting a business or getting a further education. Most of them wanted to start a job. Campus employment was their first choice. About $17 \%$ of the students chose off campus job interviews and another $17 \%$ percentage of them decided to find the job on line. Only $6 \%$ of them wanted to apply for a job through the recommendation of a family or friend. Coming from the countryside and lacking in family background might be the main cause of it (Zhang, 2011).

\subsubsection{Employment Intention}

Three factors affected the students' job hunting, the ownership of the working unit, the employment area and whether the position suited their training or not. It is especially important for us to know the needs of the students.

According to the Table 2, only $16 \%$ of the students were ready to take the job whatever it matched the specialty or not. Most of them thought they can take the advantage of the major by taking the job which suit their training. With respect to the question- “ownership of working unit”, about $45 \%$ of them chose the option "I don't care”. It showed the students cared more about their future development instead of the ownership of working unit. In respect of the "employment area”, about 31\% of the students chose Pearl River Delta, about a third of the students chose Yangtze River Delta, the rest of them chose the middle part and other places.

To the "vocational counsel and service", about $28 \%$ of the students would like to have the school recommendation. About $21 \%$ of them were desirous to have the guidance of job-hunting skills. About a third of the students wanted to have the previous employment data and about $18 \%$ of the students wanted to know the employment policy. It showed that colleges should strengthen on students’ career guidance.

\subsubsection{Psychology in Job-Hunting}

In order to learn about the "ownership of working unit" of the students during job-hunting, we carried out the survey.

As can be seen in Table 3, only ten percent of the students were not in a hurry to find a job. $73 \%$ of them were a little anxious. 17 percent of the students were worried about or very anxious about it. 34\% of them were trying their very best to find the job, but half of the students were playful. The percentage of the slack students was 16 percent. The students showed different psychology in job-hunting, we should pay close attention to their psychology change and provide them with the guidance if necessary.

\subsubsection{Employment Value}

Graduates have different value proposition in the job seeking process. Some of them put great stock in their earnings, the others paid attention to the opportunities for development.

On the basis of the survey (Table 4), students were careful about their further development when they were seeking the employment. $45 \%$ of the students wanted to get the personal development, $31 \%$ of them wanted to learn skill, $18 \%$ of the students paid attention to their income. About the monthly pay standard, more than half of the students selected "2000 - 3000 yuan", 23\% of them selected "1500 - 2000 yuan", 18\% of the students wanted to get more than 3000 yuan, only few of them can accept 1500 yuan.

\subsection{Interview Situation}

The author interviewed 150 students by cooperating with her working staff. The interview reflected some typical problems. 
Table 1. Employment preparation.

\begin{tabular}{ccccccccc}
\hline \multicolumn{1}{c}{ Item content } & \multicolumn{3}{c}{ After graduation } & \multicolumn{4}{c}{ Employment channels } \\
\hline Option & Get a job & $\begin{array}{c}\text { Start a } \\
\text { business }\end{array}$ & $\begin{array}{c}\text { Continuing } \\
\text { education }\end{array}$ & $\begin{array}{c}\text { No } \\
\text { decision }\end{array}$ & $\begin{array}{c}\text { Campus job } \\
\text { interviews }\end{array}$ & $\begin{array}{c}\text { Off campus job } \\
\text { interviews }\end{array}$ & $\begin{array}{c}\text { On line job } \\
\text { hunting }\end{array}$ & $\begin{array}{c}\text { Recommendation of } \\
\text { a family or friend }\end{array}$ \\
\hline Number of people & 558 & 60 & 48 & 60 & 432 & 126 & 126 & 42 \\
Proportion & $77 \%$ & $8 \%$ & $7 \%$ & $8 \%$ & $60 \%$ & $17 \%$ & $17 \%$ & $6 \%$ \\
\hline
\end{tabular}

Table 2. Intention of employment.

\begin{tabular}{|c|c|c|c|c|c|c|c|c|}
\hline \multirow[t]{2}{*}{ Item content } & \multicolumn{4}{|c|}{$\begin{array}{l}\text { Do you want to take the job that does not suit your } \\
\text { training? }\end{array}$} & \multicolumn{4}{|c|}{ Ownership of working unit } \\
\hline & Willing & Unwilling & $\begin{array}{l}\text { Change } \\
\text { the profession }\end{array}$ & Don't care & $\begin{array}{l}\text { Stated-own } \\
\text { ed business }\end{array}$ & $\begin{array}{l}\text { Private } \\
\text { enterprise }\end{array}$ & $\begin{array}{l}\text { Overseas-funded } \\
\text { enterprises }\end{array}$ & Don’t care \\
\hline Number of people & 116 & 392 & 65 & 152 & 152 & 138 & 109 & 327 \\
\hline Proportion & $16 \%$ & $54 \%$ & $9 \%$ & $21 \%$ & $21 \%$ & $19 \%$ & $15 \%$ & $45 \%$ \\
\hline \multirow[t]{2}{*}{ Item content } & \multicolumn{4}{|c|}{ Employment area } & \multicolumn{4}{|c|}{ What kind of counsel and service do you want to get } \\
\hline & $\begin{array}{l}\text { Pearl River } \\
\text { Delta }\end{array}$ & $\begin{array}{c}\text { Yangtze } \\
\text { River Delta }\end{array}$ & Middle part & Other & $\begin{array}{l}\text { School } \\
\text { referral }\end{array}$ & $\begin{array}{l}\text { Job-hunting } \\
\text { skills }\end{array}$ & $\begin{array}{l}\text { Previous } \\
\text { employment data }\end{array}$ & $\begin{array}{l}\text { Employment } \\
\text { policy }\end{array}$ \\
\hline Number of people & 225 & 240 & 203 & 58 & 204 & 150 & 236 & 136 \\
\hline Proportion & $31 \%$ & $33 \%$ & $28 \%$ & $8 \%$ & $28 \%$ & $21 \%$ & $33 \%$ & $18 \%$ \\
\hline
\end{tabular}

Table 3. Employment psychology.

\begin{tabular}{|c|c|c|c|c|c|c|c|c|}
\hline \multirow[t]{2}{*}{ Item content } & \multicolumn{4}{|c|}{ Thinking of you self during job-hunting } & \multicolumn{4}{|c|}{ Attitude towards employment } \\
\hline & $\begin{array}{c}\text { Try very } \\
\text { hard }\end{array}$ & Harder & Unseriousness & Slackness & Unworried & $\begin{array}{l}\text { A little } \\
\text { anxious }\end{array}$ & $\begin{array}{l}\text { Worry } \\
\text { about }\end{array}$ & $\begin{array}{c}\text { Very anxious } \\
\text { about }\end{array}$ \\
\hline number of people & 36 & 211 & 363 & 116 & 72 & 528 & 108 & 18 \\
\hline proportion & $5 \%$ & $29 \%$ & $50 \%$ & $16 \%$ & $10 \%$ & $73 \%$ & $15 \%$ & $2 \%$ \\
\hline
\end{tabular}

Table 4. Employment value.

\begin{tabular}{|c|c|c|c|c|c|c|c|c|}
\hline \multirow[t]{2}{*}{ Item content } & \multicolumn{4}{|c|}{ Which do you think is the most important one } & \multicolumn{4}{|c|}{ Monthly pay standard } \\
\hline & Income & $\begin{array}{c}\text { Personal } \\
\text { development }\end{array}$ & $\begin{array}{l}\text { Learning } \\
\text { skill }\end{array}$ & $\begin{array}{c}\text { Living } \\
\text { conditions }\end{array}$ & 1500 & $1500-2000$ & $2000-3000$ & $\begin{array}{c}\text { Above } \\
3000\end{array}$ \\
\hline Number of people & 36 & 211 & 363 & 116 & 22 & 167 & 407 & 131 \\
\hline Proportion & $18 \%$ & $45 \%$ & $31 \%$ & $6 \%$ & $3 \%$ & $23 \%$ & $56 \%$ & $18 \%$ \\
\hline
\end{tabular}

\subsubsection{Exist Some Slow Learners Group}

Some students failed the exams of the main courses severely. And the credit point is on the low side. These made them lack of competitiveness in job-hunting. And some of them lost their confidence due to the flunk of so many subjects.

\subsubsection{Be Lack of Hard Working}

Some students thought that the grass-roots work and the field work were dirty, disorderly and bad. They failed to see the advantage of learning skills in these positions.

\subsubsection{Be Particular about Suiting One's Training}

We can conclude from the survey that most of the students wanted to apply for a job which match their specialty. They thought they can take the advantage of their major. But they may miss the boat owing to the requirement of suiting one's training. 
3.2.4. They Thought the Vocational Counsel and Service Provided by College Was Not Adequate According to the survey, a proportion of the students were not familiar with the policies of college students employment. Such as the employment situation, post practice, the legal binding of the agreement and the domiciliary transfer after graduation.

\subsubsection{Employing Unit Didn't Explain the Policies Clearly}

Parts of the students thought that employing units didn't explain the policies clearly. They didn't make the work treatment, job content, working hours and some sensitive problems very clear to the students. It would influence their decision. They hoped that the college can improve the communication with the employing unit (Tian, 2007).

\section{Suggestions and Thoughts}

Upon the related data of the interview and the questionnaire survey, we had got acquainted with the state of mind of graduates with difficulties in finding jobs. The author put forward a few constructive suggestions to the domestic higher vocational colleges.

\subsection{Classified Guidance, Draw up a Plan for One on One Supporting Program}

We should insist the principle of handling each case on its own merits. To the lower learners, the urgent task on hand is to help them to increase their credit point by applying reexamine. The vocational coundel training should be provided to those inarticulate students.

\subsection{Strengthen the Communication, Set Strict Demands on the Employing Unit}

The aim of communication between the competent department including the subordinate college and the employing unit is to remind them to explain the work treatment, job content, working hours and some sensitive problems clearly. Secondly, the communication skills with the employing unit, the relating propagand of related professions are important.

\subsection{Be Divided into Groups for Discussion, Specialty Recognition of Graduates Should Be Stressed}

A proportion of the students want to apply for the job which related to their training. They think they can take the advantage of the major. At the beginning of the interview, students consider that most of the jobs does not match their specialty. There may be two cases: one is that the job is really not matching the students' specialty and the other is that it is just the students' thoughts. To this problem, we should help the students to increase their major awareness.

\subsection{Make Overall Plans, to Establish Market Investigation and Study of Zoning}

According to the result of the interview and the questionnaire survey, campus employment is the students' first choice, and they want to choose the career region in the cities along the big rivers and the coast. It indicated the right road for us. We can help the students with difficulties in finding jobs to establish their electronically resume. We ought to inform them the policies of work arrangement, post practice and the peak time of recruitment fair immediately. Bringing in high-quality employment unit is another way.

The subordinate college can make out their market investigation and study plan according to the date of the interview and the questionnaire survey, and then deliver it to the employment department. The employment department can plan it for entire project.

We should bring into full play the imitative, wisdom and power of the professional teachers.

In order to get more enrollment plan, we could pay return visit to the important research regions.

\section{References}

Qiu, R. F. (2011). A Study of Ideological and Political Education of the Basic Structure and Function of. The Discourse of Ideological and Political Education, 51-52. 
Tian, X. (2007). On the Socialist Studies. The Effectiveness of Ideological and Political Education in Colleges China Feature Enhancement,107-109.

Yang, H. Z. (2013). Study on the Effectiveness of Ideological and Political Education for College Students. Ph.D. Thesis, Changchun: Northeast Normal University.

Zhang, J. (2011). New Media Environment of Modern Ideological and Political Education Power Generation. School Party Building and Ideological and Political Education, 46-48. 